\title{
STRATEGI PENGEMBANGAN BADAN USAHA MILIK DESA (BUMDES) BERBASIS PERTANIAN DI KABUPATEN SUMBAWA BARAT
}

\author{
Muhammad Nursan*1, Aeko Fria Utama FR ${ }^{1}$ \\ ${ }^{1}$ Program Studi Agribisnis Fakultas Pertanian Universitas Mataram \\ Email: mnursan@yahoo.co.id
}

\begin{abstract}
One of the efforts to develop village economic in West Sumbawa Regency is to establish and develop Village Owned Enterprise (Bumdes) based on agriculture. The purpose of this research is to find out internal and external factors of Bumdes based on agriculture; and formulating strategies for developing Bumdes based on agriculture in West Sumbawa Regency. This research was conducted in West Sumbawa Regency. 40 respondents were selected by purposive sampling. This research method is survey method. The instrument validity test was carried out with the Pearson Product Moment correlation technique, and for the reliability test with the Cronbach Alpha formula. Data collected were analysed using SWOT analysis. The results show that internal factors in the form of the main strength of Bumdes based on agriculture is the business managed by Bumdes serving the basic needs of community, while the main weakness is the capacity of managers managing Bumdes still lacking, and the absence of marketing networks. For external factors, the main opportunities of Bumdes based on agriculture are the support of local and central government regulations, the area and potential of agriculture can be developed optimally as well as the development and expansion of agricultural businesse, while the main threats of Bumdes are the lack of community participation in Bumdes activities. Results of SWOT analysis, the strategy Bumdes based on agriculture in West Sumbawa Regency can be done using the W-O (Weakness-opportunity) strategy, which is a strategy that minimizes the weaknesses that are owned to seize opportunities.
\end{abstract}

Keywords: Analysis. SWOT, Agriculture, Development Strategy, Village Owned Enterprise, West Sumbawa Regency

\section{PENDAHULUAN}

Pembangunan ekonomi pedesaan merupakan suatu hal yang penting untuk dilakukan mengingat bahwa pembangunan ekonomi nasional harus di mulai dari desa. Selain itu, wilayah pedesaan masih mengalami permasalahan kemiskinan yang tinggi yaitu 16,31 juta atau $13,47 \%$, jika dibandingkan dengan wilayah perkotaan yaitu 10,27 juta dengan persentase 7,26\% (BPS Indonesia, 2018). Oleh karena itu, salah satu upaya pemerintah untuk mengatasi masalah ketimpangan antara pedesaan dan perkotaan yaitu perlu melaksanakan pembangunan nasional yang menaruh perhatian besar terhadap pembangunan desa (Putra, et al., 2013).

Saat ini, pemerintah telah memberikan dukungan dana dan wewenang kepada desa untuk mengatur sendiri pembangunannya yaitu melalui Undang-Undang Tentang Desa Nomor 6 Tahun 2014. Salah satu tujuan pengaturan desa yang terdapat dalam undang-undang tersebut yaitu untuk memajukan perekonomian masyarakat desa serta mengatasi kesenjangan pembangunan nasional. Selain itu, tujuan pembangunan desa yaitu untuk meningkatkan kesejahteraan masyarakat desa dan kualitas hidup manusia serta penanggulangan kemiskinan melalui pemenuhan kebutuhan dasar, pembangunan sarana dan prasarana Desa, 
pengembangan potensi ekonomi lokal, serta pemanfaatan sumber daya alam dan lingkungan secara berkelanjutan (UU Desa, 2014). Dengan adanya otoritas desa tersebut, maka pembangunan desa perlu disusun dan direncanakan secara partisipatif, yaitu dengan melibatkan berbagai unsur masyarakat desa yang terdiri atas tokoh masyarakat, tokoh agama, pemangku adat, ketua RT/RW, ketua organisasi kemasyarakatan, ketua organisasi perempuan, LSM, dan lain-lain (Nurcholis, 2011).

Dukungan terhadap pembangunan ekonomi desa berdasarkan amanat Undang-Undang Tentang Desa Nomor 6 Tahun 2014 telah diperkuat dengan diterbitkan Peraturan Menteri Desa, Pembangunan Daerah Tertinggal, dan Transmigrasi Nomor 5 Tahun 2015 Tentang Penetapan Prioritas Penggunaan Dana Desa Tahun 2015 yang menyebutkan bahwa dana desa harus diprioritaskan untuk membiayai belanja pembangunan dan pemberdayaan masyarakat desa sesuai kesepakatan dalam musyawarah desa (Menteri Desa Menteri Desa, Pembangunan Daerah Tertinggal, dan Transmigrasi, 2015). Dengan adanya prioritas dana desa ini maka setiap desa harus melakukan pembangunan desa salah satunya melalui pengembangan potensi ekonomi lokal. Salah satu upaya yang bisa dilakukan untuk mengembangkan ekonomi desa yaitu melalu kewirausahaan desa, yang dapat menjadi strategi dalam pengembangan dan pertumbuhan kesejahteraan masyarakat desa (Ansari, 2016). Kemudian Prabowo (2014), menambahkan bahwa kewirausahaan desa dapat dikembangkan melalui pendirian Badan Usaha Milik Desa (Bumdes).

Pendirian dan pengembangan Bumdes merupakan salah satu prioritas penggunaan dana desa dalam rangka meningkatkan pendapatan masyarakat Desa, Pendapatan Asli Desa dan perekonomian desa. Menurut UU Desa No. 6 tahun 2014), Bumdes merupakan badan usaha yang seluruh atau sebagian besar modalnya dimiliki oleh Desa melalui penyertaan secara langsung yang berasal dari kekayaan Desa yang dipisahkan guna mengelola aset, jasa pelayanan, dan usaha lainnya untuk sebesar-besarnya kesejahteraan masyarakat Desa. Selain itu, Ridlwan (2014) menjelaskan bahwa kegiatan ekonomi Bumdes merupakan bagian dari usaha peningkatan ekonomi desa dan daerah dalam lingkup perekonomian nasional.

Di samping itu, wilayah pedesaan tidak dapat dilepaskan dari sektor pertanian, mengingat peran dan pentingnya sektor pertanian sebagai sektor utama (leading sector) dalam meningkatkan perekonomian pedesaan. Menurut Daryanto (2009), sektor pertanian berperan penting sebagai sektor penghasil pangan dan bahan baku sektor industri dan jasa, penghasil atau penghemat devisa dari ekspor atau substitusi impor produk pertanian, pasar potensial bagi produk-produk industri, transfer surplus tenaga kerja dari sektor pertanian ke sektor industri, dan sektor pertanian menjadi modal pengembangan sektor-sektor lainnya (a net outflow of capital for invesment in others sectors). Selain itu, sektor pertanian juga mampu menghasilkan pertumbuhan yang berpihak pada penduduk miskin melalui penciptaan peluang pasar baru yang bermanfaat bagi penduduk miskin pedesaan (Hanjra \& Culas, 2011). Mengingat pentingnya peran sektor pertanian tersebut bagi perekonomian pedesaan, maka usaha Bumdes perlu diarahkan atau dikembangkan dengan kegiatan usaha berbasis pertanian.

Kabupaten Sumbawa Barat merupakan salah satu kabupaten di Provinsi Nusa Tenggara Barat yang telah mendirikan dan menjalankan usaha Bumdes berbasis pertanian. Di mana pada tahun 2018 dari 57 desa yang ada di Kabupaten Sumbawa Barat, terdapat sebanyak 48 desa yang telah memiliki Bumdes. Jenis usaha yang dilakukan oleh Bumdes sangat beragam mulai dari simpan pinjam, penyewaan aset desa, pengelolaan sampah, air 
bersih, dan usaha di bidang pertanian (DPMD KSB, 2018). Pendirian dan pengembangan Bumdes tidak lepas dari upaya percepatan program pembangunan desa dan pemberdayaan masyarakat desa di Kabupaten Sumbawa Barat. Meskipun demikian Bumdes-Bumdes yang terdapat di Kabupaten Sumbawa Barat khususnya Bumdes yang bergerak di usaha berbasis pertanian masih mengalami kendala dalam menjalankan dan mengembangkan usahanya. Oleh karena itu, tujuan penelitian ini adalah untuk mengetahui faktor-faktor internal dan eksternal yang dihadapi oleh Bumdes yang berbasis pertanian di Kabupaten Sumbawa Barat; dan Merumuskan strategi pengembangan Bumdes berbasis pertanian di Kabupaten Sumbawa Barat.

\section{METODE PENELITIAN}

Penelitian ini dilaksanakan di Kabupaten Sumbawa Barat pada empat kecamatan yaitu Kecamatan Poto Tano, Kecamatan Taliwang, Kecamatan Bran Ene dan Kecamatan Maluk yang dipilih secara purposive sampling di mana pada wilayah tersebut terdapat Bumdes berbasis pertanian. Pemilihan responden dilakukan secara purposive sampling terhadap 40 responden yang diambil menggunakan teknik proporsional random sampling. Metode yang digunakan pada penelitian ini adalah metode penelitian survei dengan pendekatan analisis deskriptif. Data penelitian terdiri atas data primer dan sekunder mengenai kondisi dan faktorfaktor internal dan eksternal Bumdes berbasis pertanian di Kabupaten Sumbawa Barat. Pengumpulan data dilakukan dengan menggunakan teknik wawancara dengan instrumen penelitian berupa kuesioner. Uji validitas instrumen dilakukan dengan teknik korelasi Product Moment Pearson, dan untuk uji reabilitas digunakan rumus Alpa Cronbach.

Data yang terkumpul kemudian dianalisis menggunakan analisis SWOT (strength, weakness, opportunity, threats) yaitu identifikasi sistematis terhadap berbagai faktor untuk merumuskan strategi perusahaan. Analisis ini berdasarkan pada logika memaksimalkan kekuatan (strength) dan memanfaatkan peluang (opportunity), namun secara bersamaan juga dapat meminimalkan kelemahan (weakness) dan menghindari ancaman (threats) dalam rangka merumuskan strategi (Rangkuti, 2015).

\section{Hasil Uji Validitas dan Reabilitas}

\section{HASIL DAN PEMBAHASAN}

Uji Validitas digunakan untuk mengetahui kemampuan instrumen dalam mengukur apa yang seharusnya diukur (Sumanto, 2014). Pada penelitian ini pengumpulan data dilakukan terhadap 40 responden sehingga nilai $r$ tabel sebesar 0.413 . Jika $r$ hitung $>r$ tabel maka semua pertanyaan dapat dikatakan valid begitu juga sebaliknya. Berdasarkan hasil analisis validitas menggunakan teknik korelasi Product Moment Pearson diperoleh nilai r hitung > r tabel yaitu sebesar $0.675>0.413$, ini berarti bahwa semua pertanyaan dikatakan valid.

Selain itu, pada penelitian ini juga dilakukan uji reabilitas untuk mendapatkan kesesuaian data dengan tujuan pengukuran (Sujianto, 2009). Berdasarkan hasil uji reabilitas diperoleh nilai Alpha Cronbach sebesar 0.93, lebih besar dari 0.60 sehingga dapat dikatakan reliabel. 


\section{Profil Bumdes Berbasis Pertanian}

Bumdes merupakan badan usaha yang seluruh atau sebagian besar modalnya dimiliki oleh Desa melalui penyertaan secara langsung yang berasal dari kekayaan Desa yang dipisahkan guna mengelola aset, jasa pelayanan, dan usaha lainnya untuk sebesar-besarnya kesejahteraan masyarakat desa. Bumdes didirikan sebagai upaya menampung seluruh kegiatan dibidang ekonomi dan atau pelayanan umum yang dikelola oleh Desa dan/atau kerja sama antar Desa (UU Desa, 2014).

Kabupaten Sumbawa Barat memiliki Bumdes sebanyak 48 dengan jenis usaha yang dilakukan oleh Bumdes sangat beragam mulai dari simpan pinjam, penyewaan aset desa, pengelolaan sampah, air bersih, dan perdagangan usaha pertanian. Dari keseluruhan Bumdes terdapat sebanyak 10 Bumdes atau $20 \%$ berbasis pada sektor usaha pertanian seperti usaha peternakan, pertanian pangan dan usaha perikanan. Jumlah modal Bumdes berbasis pertanian di Kabupaten Sumbawa Barat pada saat awal berdiri berkisar antara Rp 20.000.000 - Rp 200.000.000 (DPMD KSB, 2018). Pada penelitian ini yang dimaksud dengan Bumdes berbasis pertanian di Kabupaten Sumabawa Barat adalah Bumdes yang usaha utamanya berbasis sektor pertanian seperti penjualan benih, penjemuran jagung, kapal penangkap ikan, penyaluran pupuk dan peternakan ayam ras.

\section{Faktor Internal Bumdes Berbasis Pertanian}

Faktor-faktor internal yang mempengaruhi kinerja Bumdes berbasis pertanian secara umum dibedakan atas faktor yang mendukung (kekuatan) dan faktor yang tidak mendukung (kelemahan). Kekuatan dan kelemahan internal merupakan aktivitas terkontrol suatu organisasi yang mampu dijalankan dengan sangat baik atau buruk. Kondisi internal Bumdes berbasis pertanian dikaji layaknya organisasi, baik dalam konteks organisasi publik dan komersial. Dua konsep ini dipergunakan, karena peran dari Bumdes dalam UU Nomor 6 Tahun 2014 adalah peran komersial dan sosial. Aspek internal yang dikaji pada penelitian ini adalah kondisi SDM, kelembagaan, kondisi produksi, kondisi keuangan, kondisi pemasaran dan sarana prasarana yang memberikan gambaran potensi kekuatan dan kelemahan internal Bumdes. Berdasarkan kondisi yang ada sekarang, maka yang menjadi kekuatan Bumdes berbasis pertanian di Kabupaten Sumbawa Barat adalah sebagai berikut:

1. Legalitas pembentukan Bumdes sesuai dengan UU No. 6 Tahun 2014 tentang desa.

2. Pendiriannya mudah (musyawarah masyarakat dan aparatur desa)

3. Bidang usaha Bumdes yang dikelola melayani kebutuhan dasar masyarakat

4. Adanya sarana dan prasarana usaha Bumdes berbasis pertanian

Faktor kelemahan (weaknesses) merupakan situasi ataupun kondisi yang merupakan kelemahan dari Bumdes pada saat ini. Berdasarkan kondisi yang ada sekarang, maka yang menjadi faktor kelemahan Bumdes berbasis pertanian di Kabupaten Sumbawa Barat yaitu sebagai berikut:

1. Pendanaan Bumdes berbasis pertanian belum menjadi prioritas desa

2. Kapasitas SDM pengelola Bumdes berbasis pertanian masih kurang terampil baik administrasi dan keuangan

3. Masih kurangnya modal usaha Bumdes berbasis pertanian

4. Kinerja pengurus dalam mengembangkan usaha Bumdes berbasis pertanian masih kurang

5. Belum adanya media promosi dan informasi Bumdes berbasis pertanian yang memadai

6. Belum adanya jaringan pemasaran yang baik 
7. Kurangnya kualitas kemasan dan brand produk Bumdes berbasis pertanian.

\section{Faktor Eksternal Bumdes Berbasis Pertanian}

Faktor-faktor eksternal yang mempengaruhi pengembangan Bumdes berbasis pertanian di Kabupaten Sumbawa Barat secara umum dibedakan atas faktor peluang dan hambatan. Aspek yang akan dikaji meliputi: jumlah penduduk; luas wilayah, prasarana dan sarana, pemasaran produk Bumdes, kelembagaan sosial, kelembagaan produksi, sosial budaya. Berdasarkan kondisi yang ada, adapun peluang yang dimiliki Bumdes berbasis pertanian di Kabupaten Sumbawa Barat adalah sebagai berikut:

1. Dukungan regulasi pemerintah daerah dan pusat

2. Bertambahnya jumlah penduduk sebagai konsumen produk pertanian

3. Luas wilayah dan potensi pertanian dapat dikembangkan secara optimal

4. Daya beli masyarakat dan permintaan pasar meningkat

5. Pengembangan dan perluasan usaha pertanian

6. Kondisi sosial budaya yang kondusif

7. Adanya kerja sama antar desa

8. Dukungan dari pihak swasta seperti perbankan dan perusahaan swasta

Tantangan merupakan kondisi yang harus dihadapi oleh Bumdes berbasis pertanian untuk terhadap berbagai macam faktor lingkungan yang tidak menguntungkan yang menyebabkan kemunduran. Jika tidak segera diatasi, ancaman tersebut akan menjadi penghalang bagi usaha Bumdes berbasis pertanian baik di masa sekarang maupun masa yang akan datang. Berdasarkan kondisi yang ada, tantangan yang dimiliki Bumdes berbasis pertanian di Kabupaten Sumbawa Barat yaitu sebagai berikut:

1. Kurangnya dukungan pembiayaan dari pemerintah daerah dan desa di mana pemerintah desa dapat dengan mudah menarik penyertaan modalnya

2. Kurangnya partisipasi masyarakat dalam kegiatan Bumdes berbasis pertanian

3. Rentan dengan kepentingan politik kepala desa;

4. Pada kegiatan kerja sama, rentan dengan kepentingan masing-masing desa (ego sektoral).

\section{Analisis Faktor Internal dan Faktor Eksternal}

Berdasarkan identifikasi faktor-faktor internal dan eksternal Bumdes berbasis pertanian di Kabupaten Sumbawa Barat maka dapat dirumuskan alternatif strategi-strategi pengembangan sebagai berikut:

Strategi S-O (Strengths - Opportunities) yaitu dengan menggunakan kekuatan internal yang ada untuk memanfaatkan peluang eksternal, dalam mengembangkan Badan usaha milik desa bersama berbasis pertanian. Adapun rumusan strategi S-O yaitu sebagai berikut :

1. Meningkatkan pemahaman pemerintah desa dalam pembentukan badan usaha milik desa (Bumdes) berbasis pertanian

2. Pengembangan dan perluasan badan usaha milik desa berdasarkan potensi pertanian dan ekonomi desa secara berkelanjutan.

3. Meningkatkan peran masyarakat dan pihak swasta dalam pembentukan badan usaha milik desa (Bumdes) berbasis pertanian melalui musyawarah desa dan dituangkan dalam peraturan desa. 
4. Mengoptimalkan penggunaan sarana dan prasarana badan usaha milik desa dalam melakukan perluasan usaha dan meningkatkan pendapatan usaha badan usaha milik desa (Bumdes) berbasis pertanian.

5. Mengembangkan kerjas ama antar desa baik dalam pengembangan usaha maupun pembentukan badan usaha milik desa bersama berbasis pertanian sesuai dengan kebutuhan masyarakat desa.

Strategi S-T (Strengths-Threats) strategi ini bertujuan untuk menggunakan seluruh kekuatan untuk mengatasi ancaman. Adapun rumusan strategi S-T yaitu sebagai berikut :

1. Menyiapkan aturan-aturan pembentukan dan pelaksanaan badan usaha milik desa (Bumdes) berbasis pertanian dengan jelas dan tegas;

2. Menyiapkan aturan dalam rangka kerja sama badan usaha milik desa (Bumdes) berbasis pertanian yang mempunyai integritas tinggi;

3. Menyiapkan aturan kerja sama antar badan usaha milik desa (Bumdes) berbasis pertanian, yang saling menguntungkan;

4. Menyusun aturan pembiayaan badan usaha milik desa (Bumdes) berbasis pertanian, yang jelas dan tegas.

6. Meningkatkan partisipasi masyarakat desa dalam pelaksanaan kegiatan badan usaha milik desa (Bumdes) berbasis pertanian.

Strategi W-O (Weakness-Oppurtunies) yaitu strategi yang diterapkan berdasarkan pemanfaatan peluang yang ada dan meminimalkan kelemahan. Adapun rumusan strategi $\mathrm{W}-\mathrm{O}$ yaitu sebagai berikut:

1. Meningkatkan pendanaan badan usaha milik desa (Bumdes) berbasis Pertanian, dalam mengembangkan usaha dan memenuhi kebutuhan masyarakat desa.

2. Meningkatkan pengetahuan dan keterampilan pengelola badan usaha milik desa (Bumdes) berbasis Pertanian melalui pelatihan manajemen dan keuangan.

3. Meningkatkan dan mengembangkan kerja sama permodalan badan usaha milik desa (Bumdes) berbasis Pertanian dengan pihak swasta (perbankan dan CSR perusahaan swasta) dan masyarakat.

4. Mengembangkan kerja sama badan usaha milik desa (Bumdes), berbasis Pertanian, dengan pihak swasta (alfamart, indomaret dan lainnya) dalam pemasaran produk.

5. Meningkatkan nilai tambah produk badan usaha milik desa badan usaha milik desa (Bumdes) berbasis Pertanian dalam memenuhi permintaan dan selera konsumen.

6. Mengembangkan media promosi dan informasi produk dan usaha badan usaha milik desa (Bumdes) berbasis pertanian.

Strategi W-T (Weakness - Threats) yaitu strategi yang dilakukan dengan cara meminimalkan kelemahan yang ada serta menghindari ancaman. Adapun rumusan strategi W-T sebagai berikut:

1. Meningkatkan sosialisasi pembentukan badan usaha milik desa(Bumdes) berbasis Pertanian kepada pemerintahan desa, pihak swasta dan masyarakat desa.

2. Menyiapkan tenaga pendamping dan pelatih profesional dalam meningkatkan pengelolaan badan usaha milik desa (Bumdes) berbasis pertanian.

3. Menyiapkan brand dan kemasaran produk guna meningkatkan nilai tambah produk badan usaha milik desa (Bumdes) berbasis pertanian. 
Tabel 1. Analisis SWOT Strategi Pengembangan Badan Usaha Milik Desa (Bumdes) Berbasis Pertanian

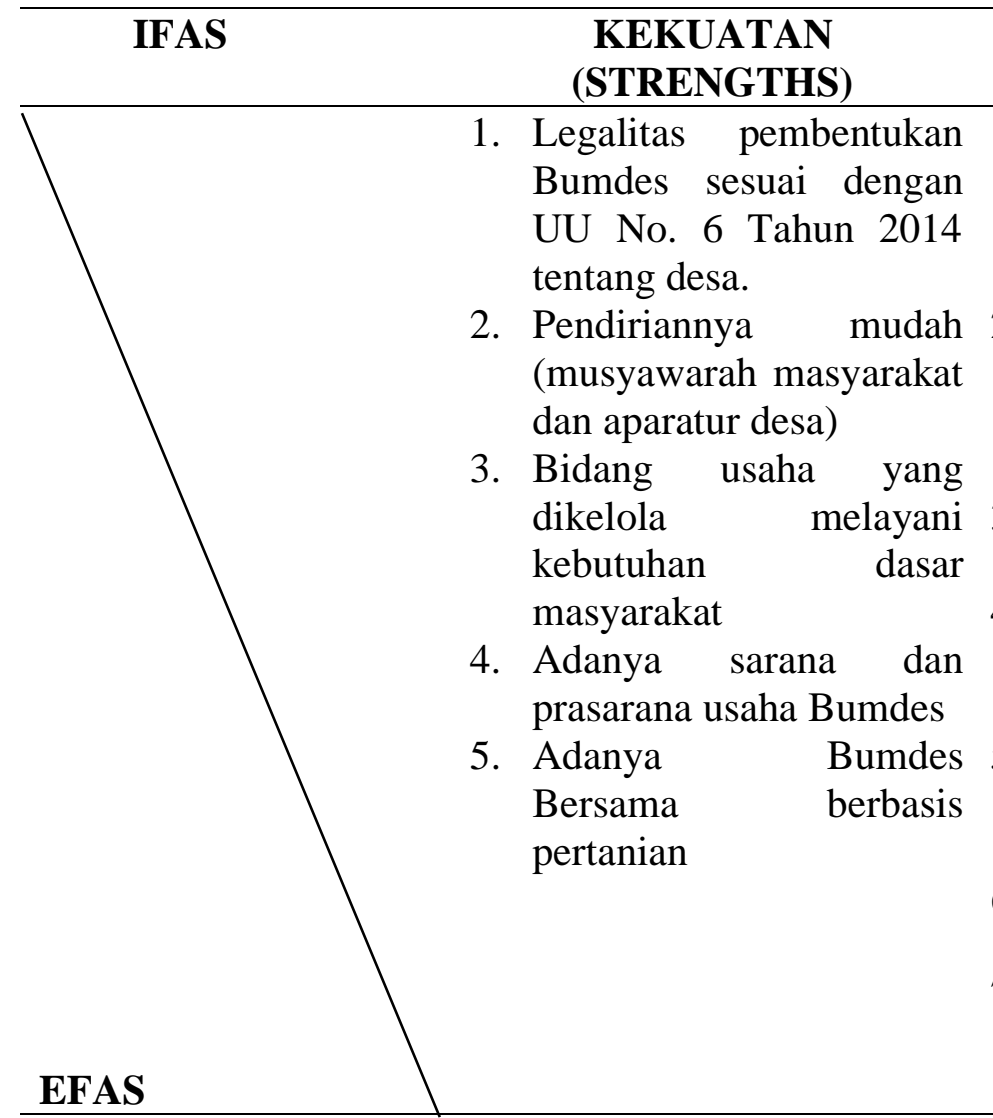

STRATEGI S-O

1. Dukungan regulasi pemerintah daerah dan pusat

2. Bertambahnya jumlah penduduk sebagai konsumen produk pertanian

3. Luas wilayah dan potensi pertanian dapat dikembangkan secara optimal

4. Daya beli masyarakat dan permintaan pasar meningkat

5. Pengembangan dan perluasan usaha pertanian

6. Kondisi sosial budaya yang kondusif

7. Adanya kerja sama antar desa O3, O5)
KELEMAHAN (WEAKNESS)

1. Pendanaan Bumdes berbasis pertanian belum menjadi prioritas desa

2. Kapasitas SDM pengelola Bumdes berbasis pertanian masih kurang terampil baik administrasi dan keuangan

3. Masih kurangnya modal usaha Bumdes berbasis pertanian

4. Kinerja pengurus dalam mengembangkan usaha Bumdes berbasis pertanian masih kurang

5. Belum adanya media promosi dan informasi Bumdes berbasis pertanian yang memadai

6. Belum adanya jaringan pemasaran yang baik

7. Kurangnya kualitas kemasan dan brand produk Bumdes berbasis pertanian STRATEGI W-O

1. Meningkatkan pendanaan badan usaha milik desa (Bumdes) berbasis pertanian dalam mengembangkan usaha dan memenuhi kebutuhan masyarakat desa (W1,W2,O2,O3,O4,O5)

2. Pengembangan dan perluasan badan usaha milik desa berdasarkan potensi pertanian dan ekonomi desa secara berkelanjutan (S1, S2, S3,

2. Meningkatkan pengetahuan dan keterampilan pengelola badan usaha milik desa (Bumdes) berbasis pertanian melalui pelatihan manajemen dan keuangan (W2,W4,O1, $\mathrm{O} 5,06,07,08)$

3. Meningkatkan peran 3. Meningkatkan dan masyarakat dan pihak mengembangkan kerja sama swasta dalam pembentukan badan usaha milik desa (Bumdes) berbasis pertanian melalui musyawarah desa dan dituangkan dalam peraturan desa (S1, S2, 4. Mengembangkan kerja sama 


\begin{tabular}{|c|c|c|}
\hline $\begin{array}{llr}\text { 8. } & \begin{array}{l}\text { Dukungan } \\
\text { pihak }\end{array} & \text { dari } \\
\text { swasta } \\
\text { seperti } & \text { perbankan } \\
\text { dan } & \text { perusahaan } \\
\text { swasta } & \end{array}$ & 5. & 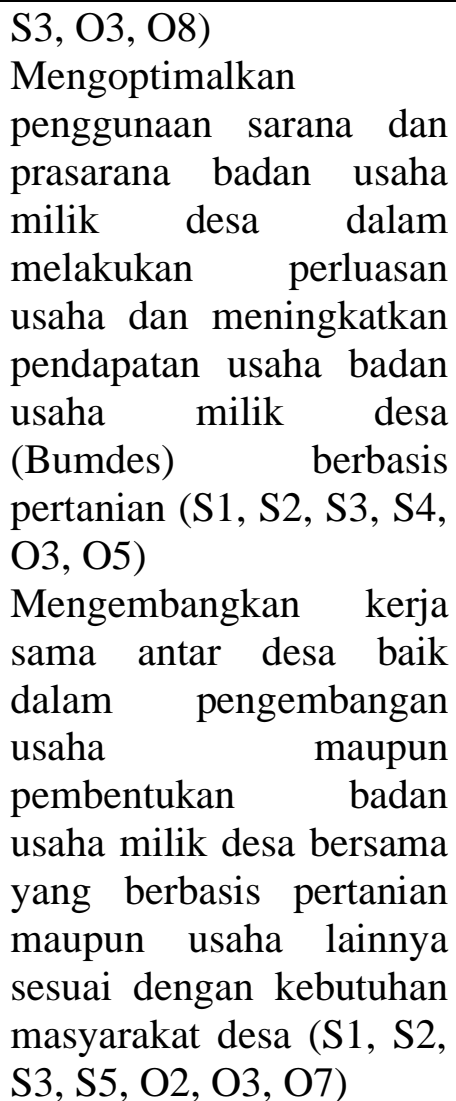 \\
\hline
\end{tabular}

badan usaha milik desa (Bumdes) berbasis pertanian dengan pihak swasta (alfamart, Indomaret dan lainnya) dalam pemasaran produk (W2,W6,O1, O5,06,07,08)

5. Meningkatkan nilai tambah produk badan usaha milik desa badan usaha milik desa (Bumdes) berbasis pertanian dalam memenuhi permintaan dan selera konsumen (W1,W5,W6,O2,O3,O4,O5)

6. Mengembangkan media promosi dan informasi produk dan usaha badan usaha milik desa (Bumdes) berbasis pertanian (W1,W5,W6,O2,O3,O4,O5)

\section{ANCAMAN}

\section{(THREATS)}

1. Kurangnya

dukungan

pembiayaan dari pemerintah daerah dan desa di mana pemerintah desa dapat dengan mudah menarik penyertaan modalnya

2. Kurangnya partisipasi masyarakat dalam kegiatan Bumdes berbasis pertanian

3. Rentan dengan kepentingan politik kepala desa;

4. Pada kegiatan kerja sama, rentan dengan kepentingan masing-masing desa (ego sektoral).
1. Menyiapkan aturan-aturan pembentukan dan pelaksanaan badan usaha milik desa (Bumdes) berbasis pertanian dengan jelas dan tegas (S1,S2,T2,T3,T4)

2. Menyiapkan aturan dalam rangka kerja sama badan usaha milik desa (Bumdes) berbasis pertanian yang mempunyai integritas tinggi; (S1,T4)

3. Menyiapkan aturan kerja sama antar badan usaha milik desa (Bumdes) berbasis pertanian yang saling menguntungkan (S1,S2,T2,T3,T4)

4. Menyusun aturan pembiayaan badan usaha milik desa (Bumdes) berbasis pertanian yang jelas dan tegas $(\mathrm{S} 2, \mathrm{~T} 2)$
1. Meningkatkan sosialisasi pembentukan badan usaha milik desa(Bumdes) berbasis pertanian kepada pemerintahan desa, pihak swasta dan masyarakat desa (W1,W3,T1,T2)

2. Menyiapkan tenaga pendamping dan pelatih profesional dalam meningkatkan pengelolaan badan usaha milik desa (Bumdes) berbasis pertanian (W2,W4,T1,T2)

3. Menyiapkan brand dan pemasaran produk guna meningkatkan nilai tambah produk badan usaha milik desa (Bumdes) berbasis pertanian (W1,W3,W7,T1,T2) 
Dari hasil identifikasi faktor internal dan eksternal serta alternatif strategi maka kemudian dianalisis untuk mendapatkan strategi prioritas Bumdes berbasis pertanian di Kabupaten Sumbawa Barat yaitu melalui Internal Factor Analysis Summary (IFAS) dan Eksternal Factor Analysis Summary (EFAS) yang merupakan perkalian antara rating kali bobot. Secara jelas hasil IFAS dan EFAS disajikan pada tabel di bawah ini.

Tabel 2 Hasil IFAS

\begin{tabular}{|c|c|c|c|c|}
\hline No & Faktor-Faktor Strategi Internal & Bobot & Ruting & $\begin{array}{c}\text { Bobot } \\
\mathrm{x} \\
\text { Ruting }\end{array}$ \\
\hline & Kekuatan & & & \\
\hline 1 & $\begin{array}{l}\text { Legalitas pembentukan Bumdes sesuai dengan UU No. } 6 \\
\text { Tahun } 2014 \text { Tentang Desa. }\end{array}$ & 0.05 & 4 & 0.17 \\
\hline 2 & $\begin{array}{l}\text { Pendiriannya mudah (musyawarah masyarakat dan } \\
\text { aparatur desa) }\end{array}$ & 0.04 & 3 & 0.14 \\
\hline 3 & $\begin{array}{l}\text { Bidang usaha Bumdes yang dikelola melayani kebutuhan } \\
\text { dasar masyarakat }\end{array}$ & 0.05 & 4 & 0.18 \\
\hline \multirow[t]{3}{*}{4} & $\begin{array}{l}\text { Adanya sarana dan prasarana usaha Bumdes berbasis } \\
\text { pertanian }\end{array}$ & 0.04 & 3 & 0.13 \\
\hline & & & & 0.62 \\
\hline & Kelemahan & & & \\
\hline 1 & $\begin{array}{l}\text { Pendanaan Bumdes berbasis pertanian belum menjadi } \\
\text { prioritas desa }\end{array}$ & 0.03 & 2 & 0.08 \\
\hline 2 & $\begin{array}{l}\text { Kapasitas SDM pengelola Bumdes berbasis pertanian } \\
\text { masih kurang terampil baik administrasi dan keuangan }\end{array}$ & 0.05 & 4 & 0.17 \\
\hline 3 & $\begin{array}{l}\text { Masih kurangnya modal usaha Bumdes berbasis pertanian } \\
\text { dari dana desa }\end{array}$ & 0.04 & 3 & 0.10 \\
\hline 4 & $\begin{array}{l}\text { Kinerja pengurus dalam mengembangkan usaha Bumdes } \\
\text { berbasis pertanian masih kurang }\end{array}$ & 0.04 & 3 & 0.11 \\
\hline 5 & $\begin{array}{l}\text { Belum adanya media promosi dan informasi Bumdes } \\
\text { berbasis pertanian yang memadai }\end{array}$ & 0.05 & 3 & 0.16 \\
\hline 6 & Belum adanya jaringan pemasaran yang baik & 0.05 & 4 & 0.17 \\
\hline \multirow[t]{3}{*}{7} & $\begin{array}{l}\text { Kurangnya kualitas kemasan dan brand produk Bumdes } \\
\text { berbasis pertanian }\end{array}$ & 0.03 & 2 & 0.08 \\
\hline & & & & 0.87 \\
\hline & Sumbu X (Kekuatan - Kelemahan) & & & -0.26 \\
\hline
\end{tabular}

Tabel 3 Hasil Analisis EFAS

\begin{tabular}{|c|c|c|c|c|}
\hline No & Faktor-Faktor Strategi Eksternal & Bobot & Rating & $\begin{array}{l}\text { Bobot } \\
\quad \mathrm{x} \\
\text { Rating }\end{array}$ \\
\hline & Peluang & & & \\
\hline 1 & Dukungan regulasi pemerintah daerah dan pusat & 0.05 & 4 & 0.18 \\
\hline 2 & $\begin{array}{l}\text { Bertambahnya jumlah penduduk sebagai konsumen produk } \\
\text { pertanian }\end{array}$ & 0.04 & 3 & 0.13 \\
\hline 3 & Luas wilayah dan potensi pertanian dapat dikembangkan & 0.05 & 4 & 0.18 \\
\hline
\end{tabular}


secara optimal

4 Daya beli masyarakat dan permintaan pasar meningkat

$\begin{array}{lll}0.04 & 3 & 0.13 \\ 0.05 & 4 & 0.18 \\ 0.04 & 3 & 0.09 \\ 0.03 & 2 & 0.08 \\ 0.04 & 3 & 0.13 \\ & & 1.09\end{array}$

5 Pengembangan dan perluasan usaha pertanian

\section{Ancaman}

Kurangnya dukungan pembiayaan dari pemerintah daerah dan

1 desa di mana pemerintah desa dapat dengan mudah menarik penyertaan modalnya

2 Kurangnya partisipasi masyarakat dalam kegiatan Bumdes berbasis pertanian

$\begin{array}{lll}0.04 & 3 & 0.12\end{array}$

Rentan dengan kepentingan politik kepala desa;

$\begin{array}{lll}0.05 & 4 & 0.17\end{array}$

4 Pada kegiatan kerja sama, rentan dengan kepentingan masingmasing desa (ego sektoral).

$\begin{array}{lll}0.04 & 3 & 0.12\end{array}$

$0.04 \quad 3 \quad 0.12$

Sumbu Y (Peluang - Ancaman)

\section{Strategi Pengembangan Bumdes Berbasis Pertanian di Kabupaten Sumbawa Barat}

Untuk mengetahui strategi pengembangan Bumdes berbasis pertanian di Kabupaten Sumbawa Barat maka perlu dibuat matrik space. Berdasarkan tabel IFAS dan EFAS dapat dihitung sebagai berikut:

- Kekuatan $($ Strenght $)-$ Kelemahan $($ Weakness $)=0.62-0.87=-0.26$

- Peluang (Opportunity) - Ancaman $($ Threat $)=1.09-0.53=0.57$

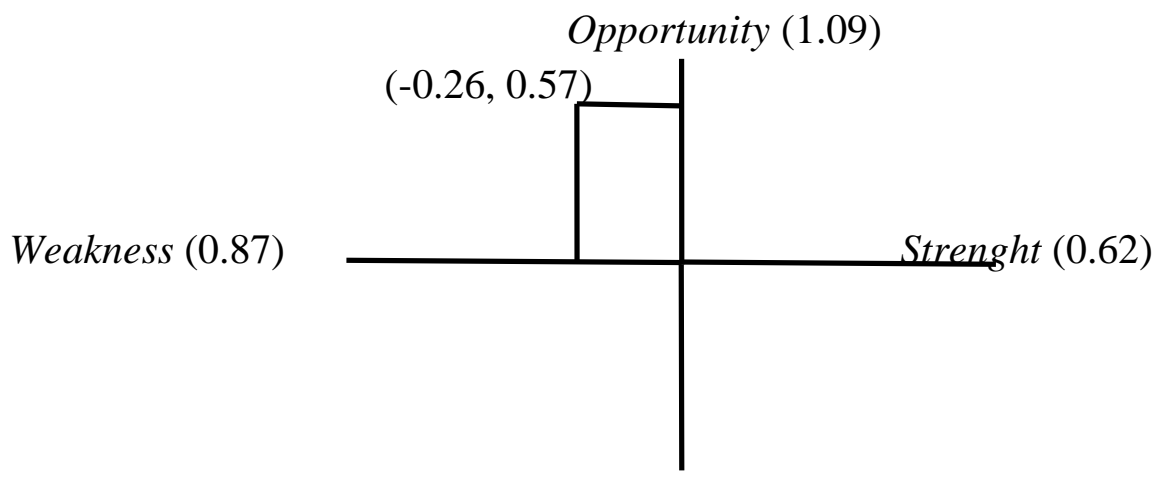

Threat (0.53)

Gambar 1. Matrik Space

Strategi pengembangan badan usaha milik desa (Bumdes) berbasis pertanian di Kabupaten Sumbawa Barat yang perlu dilakukan adalah strategi W-O (Weaknessopportunity) yaitu strategi yang meminimalkan kelemahan yang dimiliki untuk meraih peluang atau strategi Turn Around. Adapun rumusan strategi W-O tersebut yaitu sebagai berikut:

1. Meningkatkan pendanaan badan usaha milik desa (Bumdes) berbasis Pertanian dalam mengembangkan usaha dan memenuhi kebutuhan masyarakat desa. 
2. Meningkatkan pengetahuan dan keterampilan pengelola badan usaha milik desa (Bumdes) berbasis Pertanian melalui pelatihan manajemen dan keuangan.

3. Meningkatkan dan mengembangkan kerja sama permodalan badan usaha milik desa (Bumdes) berbasis Pertanian dengan pihak swasta (perbankan dan CSR perusahaan swasta) dan masyarakat.

4. Mengembangkan kerja sama badan usaha milik desa (Bumdes), berbasis Pertanian, dengan pihak swasta (alfamart, Indomaret dan lainnya) dalam pemasaran produk.

5. Meningkatkan nilai tambah produk badan usaha milik desa badan usaha milik desa (Bumdes) berbasis Pertanian dalam memenuhi permintaan dan selera konsumen.

6. Mengembangkan media promosi dan informasi produk dan usaha badan usaha milik desa (Bumdes) berbasis pertanian.

\section{Kesimpulan}

\section{KESIMPULAN DAN SARAN}

Berdasarkan hasil dan pembahasan penelitian maka dapat disimpulkan bahwa:

1. Faktor internal badan usaha milik desa (Bumdes) berbasis pertanian di Kabupaten Sumbawa Barat meliputi kekuatan (strength) dan kelemahan (weakness). Kekuatan utama Bumdes berbasis pertanian yaitu bidang usaha yang dikelola Bumdes melayani kebutuhan dasar masyarakat sedangkan kelemahan utamanya yaitu kapasitas SDM pengelola Bumdes berbasis pertanian masih kurang terampil baik administrasi dan keuangan serta belum adanya jaringan pemasaran yang baik.

2. Faktor eksternal badan usaha milik desa (Bumdes) berbasis pertanian di Kabupaten Sumbawa Barat meliputi peluang (opportunities) dan ancaman (threats). Peluang utama Bumdes berbasis pertanian yaitu adanya dukungan regulasi pemerintah daerah dan pusat, Luas wilayah dan potensi pertanian dapat dikembangkan secara optimal serta Pengembangan dan perluasan usaha pertanian sedangkan ancaman utama Bumdes berbasis pertanian yaitu masih kurangnya partisipasi masyarakat dalam kegiatan Bumdes berbasis pertanian.

3. Strategi pengembangan badan usaha milik desa (Bumdes) berbasis pertanian di Kabupaten Sumbawa Barat yang perlu dilakukan adalah strategi W-O (Weaknessopportunity) yaitu strategi yang meminimalkan kelemahan yang dimiliki untuk meraih peluang atau strategi Turn Around.

\section{Saran}

Berdasarkan hasil kesimpulan yang diperoleh maka dapat disarankan ke depan dalam rangka pengembangan badan usaha milik desa (Bumdes) berbasis pertanian di Kabupaten Sumbawa Barat yaitu sebagai berikut:

1. Diperlukan peran pemerintah dalam melakukan kegiatan atau program-program pengembangan badan usaha milik desa (Bumdes) berbasis pertanian baik melalui pelatihan dan pendampingan Bumdes serta melakukan sosialisasi sampai ke tingkat desa.

2. Peningkatan peran stake holder dan masyarakat dalam pembentukan dan pengembangan badan usaha milik desa bersama berbasis pertanian baik dalam perencanaan, pelaksanaan maupun pendanaan dan kerja sama. 


\section{DAFTAR PUSTAKA}

Ansari, B., Seyed, M.M., Azita, Z., \& Masoumeh, A. (2013). Sustainable Entrepreneurship in Rural Areas. Research Journal of Environmental and Earth Science 5 (1): 26-31.

BPS Indonesia. (2018). Berita Resmi Statistik. Jakarta: Badan Pusat Statstik Indonesia

Daryanto, A. (2009). Dinamika Daya Saing Industri Peternakan. Bogor, IPB Press.

DPMD KSB. (2018). Data Profil Bumdes di Kabupaten Sumbawa Barat Tahun 2018. Sumbawa Barat: Dinas Pemberdayaan Masyarakat dan Desa Kabupaten Sumbawa Barat

Hanjra, M.A. \& Richard, J.C. (2011). The Political Economy of Maize Production and Poverty Reduction in Zambia: Analysis of the Last 50 Years. Journal of Asian and African Studies, 46 (6), 546-566.

Menteri Desa, Pembangunan Daerah Tertinggal, danTransmigrasi. (2015). Peraturan Menteri Desa, Pembangunan Daerah Tertinggal, danTransmigrasi Nomor 4 tahun 2015 tentang Pendirian, Pengurusan dan Pengelolaan dan Pembubaran Badan Usaha Milik Desa: Jakarta.

Menteri Desa, Pembangunan Daerah Tertinggal, dan Transmigrasi. 2015. Peraturan Menteri Desa,Pembangunan Daerah Tertinggal, dan Transmigrasi Nomor 5 Tahun 2015TentangPenetapan Prioritas Penggunaan Dana Desa Tahun 2015: Jakarta.

Nurcholis, H. (2011). Pertumbuhan dan Penyelenggaraan Pemerintahan Desa. Jakarta: Erlangga.

Prabowo, T.H.E. (2014). Developing Bumdes (Village-owned Enterprise) for Sustainable Poverty Alleviation Model Village Community Study in Bleberan-Gunung KidulIndonesia. World Applied Sciences Journal 30 (Innovation Challenges in Multidiciplinary Research E Practice): 19-26.

Putra, C.K, R.N. Ratih, N.P., \& Suwondo. (2013). Pengelolaan Alokasi Dana Desa Dalam Pemberdayaan Masyarakat Desa (Studi Pada Desa Wonorejo Kecamatan Singosari Kabupaten Malang). Jurnal Administrasi Publik, 1(6), 1203-1212.

Rangkuti, F.( 2015). Analisis SWOT Teknik Membedah Kasus Bisnis. Jakarta: PT. Gramedia.

Ridlwan, Z. (2014). Urgensi Badan Usaha Milik Desa (Bumdes) dalam Pembangunan Perekonomian. Fiat Justisia Jurnal Ilmu Hukum, 8 (3), 424-440.

Sujianto. A, E. 2009. Aplikasi Statistik Dengan SPSS. Jakarta: Prestasi Pustaka.

Sumanto. (2014). Teori dan Aplikasi Metode Penelitian. Yogyakarta: Penerbit CAPS.

Undang-Undang Nomor 6 Tahun 2014 tentang Desa. 